\title{
Mitigasi Dan Adaptasi Bencana Banjir di Kecamatan Pallangga Kabupaten Gowa (Pendekatan Kerentanan)
}

\section{Flood Disaster Mitigation And Adaptation in Pallangga District, Gowa Regency (Vulnerability Approach)}

\author{
Rasdiana. A ${ }^{1}$, Roland A. Barkey ${ }^{2}$, Syafri ${ }^{3}$ \\ ${ }^{1}$ Dinas Pekerjaan Umum dan Penataan Ruang Kota Pare-Pare \\ ${ }^{2}$ Fakultas Kehutanan, Universitas Hasanuddin \\ ${ }^{3}$ Program Studi Perencanaan Wilayah dan Kota, Program Pascasarjana, Universitas Bosowa \\ E-mail: rasdiana91@gmail.com
}

Diterima: 01 September 2021/Disetujui 12 Desember 2021

\begin{abstract}
Abstrak. Bencana banjir yang terjadi secara terus-menerus dapat menyebabkan berbagai kondisi yang apabila terjadi dapat menimbulkan berbagai kerentanan yang memerlukan pemikiran yang lebih dalam untuk mengantisipasi bencana banjir. Mitigasi dan Adaptasi Bencana Banjir di Kecamatan Pallangga Kabupaten Gowa bertujuan untuk memetakan tingkat kerentanan bencana banjir dan upaya mitigasi dan adaptasi yang tepat berdasarakan tingkat kerentanan bencana banjir di Kecamatan Pallangga. Sejalan dengan tujuan penelitian ini maka dalam penelitian ini menggunakan metode penelitian deskriptif kualitatif, untuk menentukan tingkat kerentanan dengan analisis spasial overlay dan skoring parameter penentu kerentanan banjir. Hasil dari penelitian ini adalah Kecamatan Pallangga diklasifikasi dalam tiga tingkat kerentanan bencana banjir meliputi rentan tinggi, rentan sedang dan rentan rendah serta arahan mitigasi dan adaptasi bencana banjir berdasarkan tingkat kerentanan.
\end{abstract}

Kata Kunci : Banjir, Kerentanan, Mitigasi Banjir, Gowa

\begin{abstract}
The floods disasters that occur continuously can cause various conditions which can cause a variety of vulnerabilities that require deeper thought to anticipate. Flood mitigation and adaptation in Pallangga District of Gowa aims to map the level of flood vulnerability and provide mitigation and adaptation directions based on the level of flood vulnerability in Pallangga. This research uses descriptive qualitative research methods, to determine the level of vulnerability with spatial overlay analysis and weight scoring of parameters determining flood vulnerability. The results of this research are in Pallangga classified into three levels of vulnerability to flood disasters including high vulnerability, medium vulnerability and low vulnerability with directives flood mitigation and adaptation based on the level of vulnerability.
\end{abstract}

Keywords: Flood, Vulnerabilities, Flood Mitigation, Gowa

(c) () This work is licensed under Creative Commons Attribution License 4.0 CC-BY International license

\section{Pendahuluan}

Banjir merupakan proses maluapnya air sungai ke daratan, sehingga dapat menimbulkan kerugian harta benda penduduk serta dapat menimbulkan korban jiwa. Banjir juga dapat merusak bangunan, sarana dan prasarana, lingkungan hidup, serta merusak tata kehidupan masyarakat. Untuk itu, sudah semestinya dari berbagai pihak perlu memperhatikan hal-hal yang dapat mengakibatkan banjir dan sedini mungkin diantisipasi, untuk memperkecil kerugian yang di timbulkan. (Kodoatie, J. Robert dan sugiyanto, 2002).

Pengelolaan DAS yang tepat dapat pula menjadi bentuk mitigasi bencana banjir luapan sungai. Mitigasi bencana yang terencana dengan baik dapat menciptakan ketangguhan bencana. Perencanaan mitigasi merupakan upaya-upaya yang dilakukan untuk mengurangi risiko bencana melalui pengembangan/pembangunan aspek fisik dan/atau peningkatan kesadaran dan coping capacitymasyarakat terhadap bencana (Rezende, de Franco, de Oliveira, Jacob, \& Miguez, 2019). Uraian tersebut dapat dijabarkan dan dilaksanakan secara struktural maupun non-struktural (Itsukushima, 2018). Mitigasi struktural meliputi pembangunan fisik secara keteknikan seperti pembangunan dam, tanggul buatan, saluran drainase maupun kolam tampungan, sedangkan mitigasi non-struktural meliputi aspek sosial, pendidikan, kemasyarakatan, penghijauan, dan reboisasi(Jamrussri \& Toda, 2017; Kai, Deyi, \& Zhaohui, 2016 ).

Kejadian bencana mungkin tidak bisa sepenuhnya dihilangkan, tetapi dampak dari kejadian tersebut dapat 
dikurangi (Kiedrzynska, Kiedrzynski, \& Zalewski, 2014). Seiring dengan peningkatan intensitas maupun frekuensi kejadian bencanabanjir luapan sungaimaka mitigasi secara struktural saja menjadi tidak cukup lagi untuk menanggulangi bencana banjir. Masyarakat sebagai korban yang paling terdampak ketika bencana banjir melanda merupakan objek penting yang harus ditingkatkan kapasitasnya (coping capacity) dalam menghadapi bencana tersebut. Peningkatan kapasitas masyarakat tersebut merupakan bagian dari upaya mitigasi non-struktural.

Jika kapasitas masyarakat yang tinggal pada wilayah rawan bencana banjir luapan sungai dapat ditingkatkan maka kerentanan masyarakat tersebut bencana akan menurun karena telah siap menghadapi kemungkinan terburuk. Dengan kapasitas yang baik dan tepat, masyarakat mampu melaksanakan persiapanyang lebih matang, dapat menyelamatkan keluarga, orang-orang di sekitarnya dan juga harta benda yang dimiliki ketika banjir melanda. Oleh karena itu, perencanaan mitigasi nonstruktural menjadi bagian sangat penting dalam upaya pengurangan risiko bencana karena bersentuhan langsung dengan masyarakat khususnya yang terdampak atau berpotensi terdampak bencana banjir luapan sunga (Wibowo et.all: 2019).

Provinsi Sulawesi Selatan rentan akan bencana. Selain bencana gempa bumi dan tsunami, Provinsi Sulawesi Selatan memiliki ancaman bencana lainnya seperti cuiaca ekstrim, kekeringan, tanah longsor, banjir dan bencana lainnya. Kejadian bencana tersebut menimbulkan dampak yang signifikan di Provinsi Sulawesi Selatan, yaitu baik korban jiwa, kerugian harta bencana maupun lingkungan yang rusak.

Pada bulan Januari tahun 2019 terjadi bencana banjir di beberapa Kabupaten di Provinsi Sulawesi Selatan. BNPB (Badan Nasional Penanganan Bencana) mencatat jumlah bencana pada Januari 2019 sebanyak 366 kejadian. Dari ratusan kejadian itu, bencana longsor dan banjir di Sulawesi Selatan menjadi bencana terbesar yang terjadi. Salah satunya adalah Kabupaten Gowa yang menelan 2.216 jiwa dan 604 rumah terendam banjir. Berdasarkan data bencana atau kejadian Kabupaten Gowa tahun 2019, dampak banjir terparah yaitu di Kecamatan Pallangga.

Kecamatan Pallangga secara administrasi berbatasan langsung dengan Sungai Je'neberang. Salah satu faktor bencana banjir di Kecamatan ini diakibat intensitas hujan tinggi yang mengakibatkan meluapnya air Sungai Je'neberang. Ketinggian banjir di Kecamatan Pallangga mencapai 1-3 meter.

Kedudukan Kecamatan Pallangga dalam Rencana Tata Ruang Wilayah (RTRW) Kabupaten Gowa pada rencana struktur ruang yaitu sebagai Pusat Kegiatan Nasional (PKN) Maminasata dan Pusat Pelayanan Lokal (PPL) sebagai pusat permukiman Pallangga. Pada rencana pola ruang, Kecamatan Pallangga di peruntukan sebagai kawasan permukiman, kawasan pertanian lahan basah, dan kawasan pertanian lahan kering. Kecamatan Pallangga sebagai daerah yang sering terjadi banjir, adanya peruntukan ini akan mempengaruhi kerentanan bencana dari segi ekonomi, sosial, fisik dan lingkungan, sehingga akan memengaruhi tingkat risiko bencana banjir.

\section{Metode Penelitian}

\section{a. Jenis Penelitian}

Jenis penelitian yang digunakan adalah penelitian kualitatif deskriptif. Penelitian deskriptif dimaksudkan untuk mendeskripsikan suatu situasi atau area populasi tertentu yang bersifat actual secara sistematis dan akurat dengan kata lain, tujuan penelitian deskriptif adalah mendeskripsikan seperangkat peristiwa atau kondisi populasi saat ini, menemukan makna-makna baru, menjelaskan kondisi keberadaan dan mengkategorikan informasi (Danim, 2002).

Menurut sugiyono (2012) metode deskriptif adalah suatu metode yang digunakan untuk menggambarkan dan menganalisis suatu hasil penelitian tetapi tidak digunakan untuk membuat kesimpulan yang lebih luas. Dalam hal ini digunakan untuk menggambarkan tingkat kerentanan bencana banjir yang menjadi dasar dalam menentukan arahan mitigasi dan adaptasi di lokasi penelitian. Metode dan tahapan langkah penentuan tingkat kerentanan banjir secara geospasial yang ditentukan berdasarkan aspek fisik, sosial ekonomi dan lingkungan.

\section{b. Lokasi Penelitian}

Kecamatan Pallangga terdiri atas 16 Kelurahan/Desa denga luas 5.277,25 Ha. Secara administrasi Kecamatan Pallangga berbatasan dengan Sungai Jene'berang, sehingga memudahkan luapan air sungai masuk pada Kawasan permukiman sehingga mengakibatkan banjir. Kecamatan Pallangga merupakan terdampak banjir terparah di Kabupaten Gowa dengan ketinggian 1-3 meter dan termasuk kedalam 10 Kecamatan Rawan Banjir di Kabupaten Gowa berdasarkan data bencana dari BPBD Kabupaten Gowa.

\section{c. Informan Penelitian}

Hasil dari penelitian kualitatif adalah mendapatkan informasi yang mendalam dari masalah penelitian yang dipilih. Informan pada penelitian kualitatif dipilih untuk menjelaskan kondisi atau fakta/fenomena yang terjadi informan itu sendiri. Informan dalam penelitian ini bertujuan untuk mengetahui karakteristik masyarakat, dampak bencana dan pola adaptasi masyarakat terhadap bencana banjir. Jumlah informan dalam penelitian ini sifatnya fleksibel artinya tidak ditentukannya jumlah informan dapat ditambah di tengah proses penelitian jika informasi yang didapat dirasakan masih kurang dan dapat pula mengurangi jumlah informan jika informasi sudah cukup. Bahkan dapat mengganti informan jikaorang/subyek yang terpilih tidak kooperatif dalam menjawab wawancara.

Teknik pemilihan informan dengan praduga digunakan dalam penelitian dengan menentukan karakteristik informan berdasarkan masalah dan tujuan penelitian. Informan penelitian yang dipilih yaitu masyarakat yang berada pada kawasan rentan tinggi terhadap bencana banjir di Kecamatan Pallangga.

\section{d. Variabel Penelitian}

Variabel dalam menentukan tingkat kerentanan bencana banjir di Kecamatan Pallangga terdiri atas lima yaitu kerentanan fisik, kerentanan sosial ekonomi, dan lingkungan serta sosial ekonomi masyarakat terhadap bencana banjir yang ada di lokasi penelitian

\section{e. Instrumen Penelitian}

Instrumen Penelitian yang dipergunakan dalam penelitian ini adalah peneliti itu sendiri. Peneliti kualitatif sebagai human instrument, berfokus menetapkan focus 
penelitian, memilih informan sebagai sumber data, melakukan pengumpulan data, menilai kualitas data, menganalisis data dan menafsirkan data. Disamping peneliti sebagai instrument utama, instrument untuk melakukan untuk melengkapi data-data dan membandingkan dengan data yang telah didapatkan melalui observasi dan wawancara (Sugiyono, 2009:305-307).

\section{f. Jenis dan Sumber Data}

Data yang digunakan dalam penelitian ini adalah data primer dan data sekunder. Data primer merupakan data yang diperoleh langsung di lapangan. Sedangkan data sekunder yaitu data yang diperoleh dari data hasil olahan berbagai sumber atau instansi terkait.

1. Data primer merupakan data yang diambil oleh peneliti langsung dari sumber pertama atau tempat objek penelitian yaitu hasil wawancara dan observasi oleh peneliti secara langsung. Data tersebut adalah sebagai berikut:

- Karakteristik masyarakat

- Dampak bencana

- Pola adaptasi masyarakat

- Dokumentasi gambar lokasi

2. Data Sekunder adalah data yang diperoleh melalui media cetak dan dokumen resmi serta data-data yang diperoleh melalui instansi-instansi pemerintah maupun swasta yang ada hubungannya dengan penelitian yang dilakukan. Data sekunder meliputi data aspek dasar yaitu:

- Data curah hujan yang berasal dari Badan Meteorologi, Klimatologi, Dan Geofisika (BMKG)

- Data DEM Kabupaten Gowa diperoleh dari DEMNAS.

- Data kependudukan dari Badan Pusat Statistik Kabupaten Gowa (gowakab.bps.go.id) dan Kantor Kecamatan Pallangga. Data
Kependudukan terdiri dari: Jumlah Penduduk per Kelurahan/Desa yaitu berdasarkan jenis kelamin, berdasarkan usia, penduduk miskin serta penduduk cacat.

\section{g. Teknik Analisis}

Metode weight scorring digunakan dalam mengkuantifikasi variabel dalam perhitungan menentukan tingkat kerentanan banjir di Kecamatan Pallangga. Dalam metode ini, total skor pada tiap komoditi didapatkan dengan cara mengalikan nilai/skor pada tiap komoditi yang bersangkutan dengan nilai bobot tertentu pada tiap kriteria (dengan bobot tiap kriteria bisa berbeda), kemudian menjumlahkan nilai perkalian skor dan bobot tersebut sehingga menghasilkan nilai lalu diklasifikasi mnjadi 3 tingkat kerentanan banjir.

Salah satu metoda analisis keruangan yang dipergunakan dalam perencanaan ini adalah proses tumpang susun atau overlay antara dua atau lebih layer tematik untuk mendapatkan tematik kombinasi baru sesuai dengan persamaan yang dipergunakan. Analisis ini digunakan untuk mengetahui zona kerentanan bencana banjir di Kecamatan Pallangga Kabupaten Gowa dengan melakukan overlay peta maka diharapkan akan menghasilkan suatu gambaran yang jelas.

\section{Hasil dan Pembahasan}

Luas wilayah Kecamatan Pallangga adalah 5.277,18 Ha. Kecamatan Pallangga terdiri atas 4 kelurahan dan 12 desa. Adapun kelurahan dan desa di Kecamatan Pallangga dapat dilihat pada Tabel 1
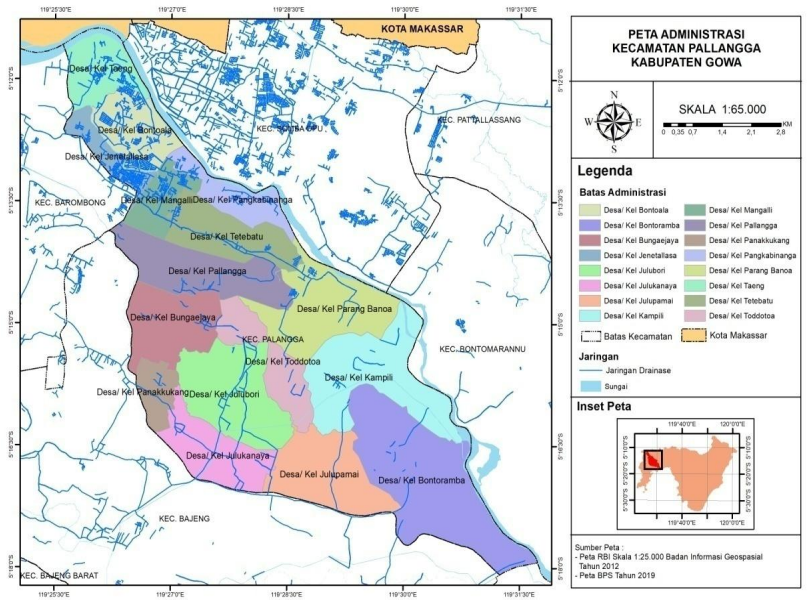

Tabel 1 Luas Kelurahan/Desa di Kecamatan Pallangga Tahun 2019

\begin{tabular}{clcr}
\hline No & \multicolumn{1}{c}{ Kelurahan/Desa } & Luas $(\mathrm{Ha})$ & Persentase $(\%)$ \\
\hline 1 & Desa Jenetallasa & 122,57 & $2,32 \%$ \\
2 & Kelurahan Tetebatu & 298,93 & $5,66 \%$ \\
3 & Desa Pallangga & 391,86 & $7,43 \%$ \\
4 & Desa Bungaejaya & 328,71 & $6,23 \%$ \\
5 & Desa Panakukang & 117,39 & $2,22 \%$ \\
6 & Desa Julukanaya & 295,99 & $5,61 \%$ \\
7 & Desa Julubori & 455,21 & $8,63 \%$ \\
8 & Desa Julupamai & 387,38 & $7,34 \%$ \\
9 & Desa Bontoramba & 802,67 & $15,21 \%$ \\
10 & Desa Kampili & 542,95 & $10,29 \%$ \\
11 & Desa Toddotoa & 243,65 & $4,62 \%$ \\
12 & Kelurahan Parangbanoa & 455,57 & $8,63 \%$ \\
13 & Kelurahan Pangkabinanga & 191,45 & $3,63 \%$ \\
14 & Desa Bontoala & 250,39 & $4,74 \%$
\end{tabular}




\begin{tabular}{clcr}
15 & Desa Mangalli & 151,71 & $2,87 \%$ \\
16 & Desa Taeng & 240,75 & $4,56 \%$ \\
\hline & Jumlah & $\mathbf{5 . 2 7 7 , 1 8}$ & $\mathbf{1 0 0 , 0 0 \%}$ \\
\hline \multicolumn{2}{c}{ Sumber $:$ BPS, Kecamatan Pallangga dalam Angka 2020 }
\end{tabular}

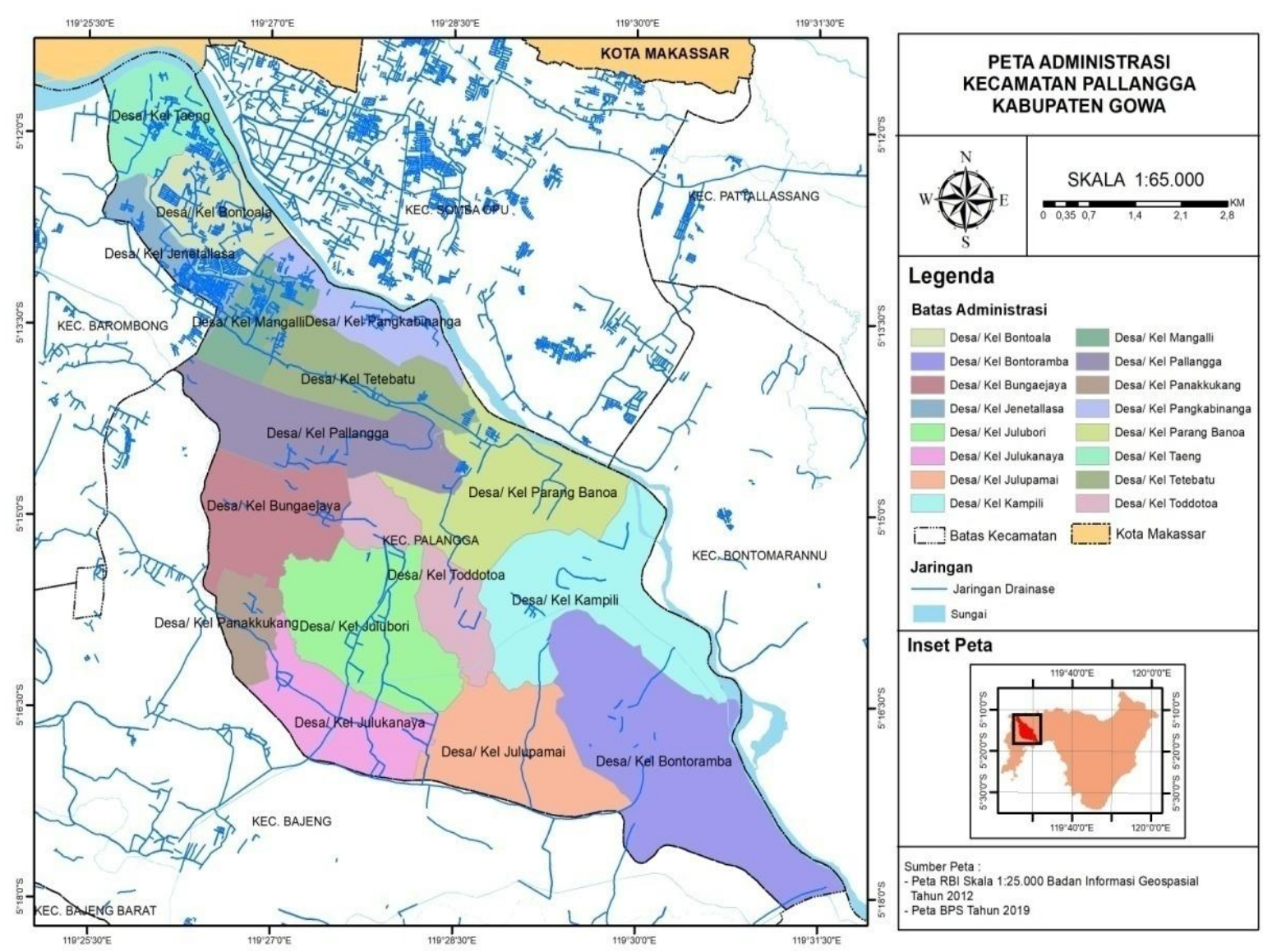

Gambar 1. Peta Administrasi Kecamatan Pallangga Kab. Gowa

Jumlah penduduk merupakan jumlah manusia yang bertempat tinggal atau berdomisili di Kecamatan Pallangga dan tercatat secara sah berdasarkan peraturan yang berlaku di daerah tersebut. Jumlah penduduk di Kecamatan Pallangga meningkat tiap tahunnya. Adapun Jumlah penduduk Kecamatan Pallangga dapat dilihat pada table 2.

Tabel 2 Jumlah Penduduk Kecamatan Pallangga Tahun 2019

\begin{tabular}{cccc}
\hline No & Kelurahan/Desa & Jumlah Penduduk & Luas (Ha) \\
\hline 1 & Desa Jenetallasa & 20.141 & 122,57 \\
2 & Kelurahan Tetebatu & 7.264 & 298,93 \\
3 & Desa Pallangga & 6.387 & 391,86 \\
4 & Desa Bungaejaya & 3.826 & 328,71 \\
5 & Desa Panakukang & 6.365 & 117,39 \\
6 & Desa Julukanaya & 5.759 & 295,99 \\
7 & Desa Julubori & 6.436 & 455,21 \\
8 & Desa Julupamai & 3.586 & 387,38 \\
9 & Desa Bontoramba & 5.668 & 802,67 \\
10 & Desa Kampili & 5.405 & 542,95 \\
11 & Desa Toddotoa & 4.002 & 243,65 \\
12 & Kelurahan Parangbanoa & 3.362 & 455,57 \\
13 & Kelurahan Pangkabinanga & 7.173 & 191,45 \\
14 & Desa Bontoala & 23.249 & 250,39 \\
15 & Desa Mangalli & 12.368 & 151,71 \\
16 & Desa Taeng & 8.965 & 240,75 \\
\hline
\end{tabular}

Sumber: BPS, Kecamatan Pallangga Dalam Angka 2020

Penentuan tingkat kerentanan berdasarkan jumlah skor dari seluruh indikator yang dikalikan dengan bobot.
Hasil nilai kerentanan diklasifikasikan menjadi tiga kelas banjir (rentan tinggi, rentan sedang dan rentan rendah) 
dengan menggunakan klasifikasi aritmatik. Pembuatan nilai interval kelas kerentanan banjir bertujuan untuk membedakan kelas kerentanan banjir antara yang satu dengan yang lain.

Hasil skoring dari setiap kerentanan memiliki peluang nilai terbesar adalah 300 sedangkan nilai terkecil 100 dengan interval 66 . berdasarkan pembagian tersebut maka dapat disimpulkan klasifikasi tingkat rentan banjir dalam setiap indikator kerentanan dapat dilihat pada tabel 13 dibawah ini.
Tabel 3. Klasifikasi Tingkat Kerentanan

\begin{tabular}{lll}
\hline No & Kelas Kerentanan & Kelas \\
\hline 1. & Rendah & $100-166$ \\
2. & Sedang & $167-233$ \\
3. & Tinggi & $234-300$ \\
\hline
\end{tabular}

Penentuan skor nilai masing-masing indikator yaitu skor dikalikan dengan bobot sehingga dihasilkan nilai dari setiap parameter. Selanjutnya penjumlahan seluruh nilai indikator untuk menentukan klasifikasi tingkat kerentanan.

\section{Kerentanan Fisik}

Analisis pembobotan Indikator Kerentanan Fisik dapat dilihat pada tabel 4 di bawah ini.

Tabel 4 Analisis Pembobotan Indikator Kerentanan fisik

\begin{tabular}{|c|c|c|c|c|c|c|}
\hline No & Kelurah/Desa & Indikator & Bobot & Skor & Nilai (bobot x Skor) & $\begin{array}{c}\text { Kelas Kerentanan } \\
\text { Fisik }\end{array}$ \\
\hline \multirow[t]{3}{*}{1} & \multirow[t]{3}{*}{ Jenetallasa } & Curah Hujan & 30 & 3 & 90 & \multirow{3}{*}{$\begin{array}{c}300 \\
\text { (tinggi) }\end{array}$} \\
\hline & & Elevasi Lahan & 30 & 3 & 90 & \\
\hline & & JAS & 40 & 3 & 120 & \\
\hline \multirow[t]{3}{*}{2} & \multirow[t]{3}{*}{ Tetebatu } & Curah Hujan & 30 & 3 & 90 & \multirow{3}{*}{$\begin{array}{c}300 \\
\text { (tinggi) }\end{array}$} \\
\hline & & Elevasi Lahan & 30 & 3 & 90 & \\
\hline & & JAS & 40 & 3 & 120 & \\
\hline \multirow[t]{3}{*}{3} & \multirow[t]{3}{*}{ Pallangga } & Curah Hujan & 30 & 3 & 90 & \multirow{3}{*}{$\begin{array}{c}260 \\
\text { (tinggi) }\end{array}$} \\
\hline & & Elevasi Lahan & 30 & 3 & 90 & \\
\hline & & JAS & 40 & 2 & 80 & \\
\hline \multirow[t]{3}{*}{4} & \multirow[t]{3}{*}{ Bungaejaya } & Curah Hujan & 30 & 3 & 90 & \multirow{3}{*}{$\begin{array}{c}260 \\
\text { (tinggi) }\end{array}$} \\
\hline & & Elevasi Lahan & 30 & 3 & 90 & \\
\hline & & JAS & 40 & 2 & 80 & \\
\hline \multirow[t]{3}{*}{5} & \multirow[t]{3}{*}{ Panakkukang } & Curah Hujan & 30 & 3 & 90 & \multirow{3}{*}{$\begin{array}{c}260 \\
\text { (tinggi) }\end{array}$} \\
\hline & & Elevasi Lahan & 30 & 3 & 90 & \\
\hline & & JAS & 40 & 2 & 80 & \\
\hline \multirow[t]{3}{*}{6} & \multirow[t]{3}{*}{ Julukanaya } & Curah Hujan & 30 & 3 & 90 & \multirow{3}{*}{$\begin{array}{c}300 \\
\text { (tinggi) }\end{array}$} \\
\hline & & Elevasi Lahan & 30 & 3 & 90 & \\
\hline & & JAS & 40 & 3 & 120 & \\
\hline \multirow[t]{3}{*}{7} & \multirow[t]{3}{*}{ Julubori } & Curah Hujan & 30 & 3 & 90 & \multirow{3}{*}{$\begin{array}{c}260 \\
\text { (tinggi) }\end{array}$} \\
\hline & & Elevasi Lahan & 30 & 3 & 90 & \\
\hline & & JAS & 40 & 2 & 80 & \\
\hline \multirow[t]{3}{*}{8} & \multirow[t]{3}{*}{ Julupamai } & Curah Hujan & 30 & 3 & 90 & \multirow{3}{*}{$\begin{array}{c}190 \\
\text { (sedang) }\end{array}$} \\
\hline & & Elevasi Lahan & 30 & 2 & 60 & \\
\hline & & JAS & 40 & 1 & 40 & \\
\hline 9 & Bontoramba & Curah Hujan & 30 & 3 & 90 & 270 \\
\hline & & Elevasi Lahan & 30 & 2 & 60 & (tinggi) \\
\hline & & JAS & 40 & 3 & 120 & \\
\hline 10 & Kampili & Curah Hujan & 30 & 3 & 90 & 300 \\
\hline & & Elevasi Lahan & 30 & 3 & 90 & (tinggi) \\
\hline & & JAS & 40 & 3 & 120 & \\
\hline 11 & Toddotoa & Curah Hujan & 30 & 3 & 90 & 220 \\
\hline & & Elevasi Lahan & 30 & 3 & 90 & (sedang) \\
\hline & & JAS & 40 & 1 & 40 & \\
\hline 12 & Parangbanoa & Curah Hujan & 30 & 3 & 90 & 300 \\
\hline & & Elevasi Lahan & 30 & 3 & 90 & (tinggi) \\
\hline & & JAS & 40 & 3 & 120 & \\
\hline 13 & Pangkabinanga & Curah Hujan & 30 & 3 & 90 & 300 \\
\hline & & Elevasi Lahan & 30 & 3 & 90 & (tinggi) \\
\hline & & JAS & 40 & 3 & 120 & \\
\hline 14 & Bontoala & Curah Hujan & 30 & 3 & 90 & 300 \\
\hline & & Elevasi Lahan & 30 & 3 & 90 & (tinggi) \\
\hline & & JAS & 40 & 3 & 120 & \\
\hline
\end{tabular}




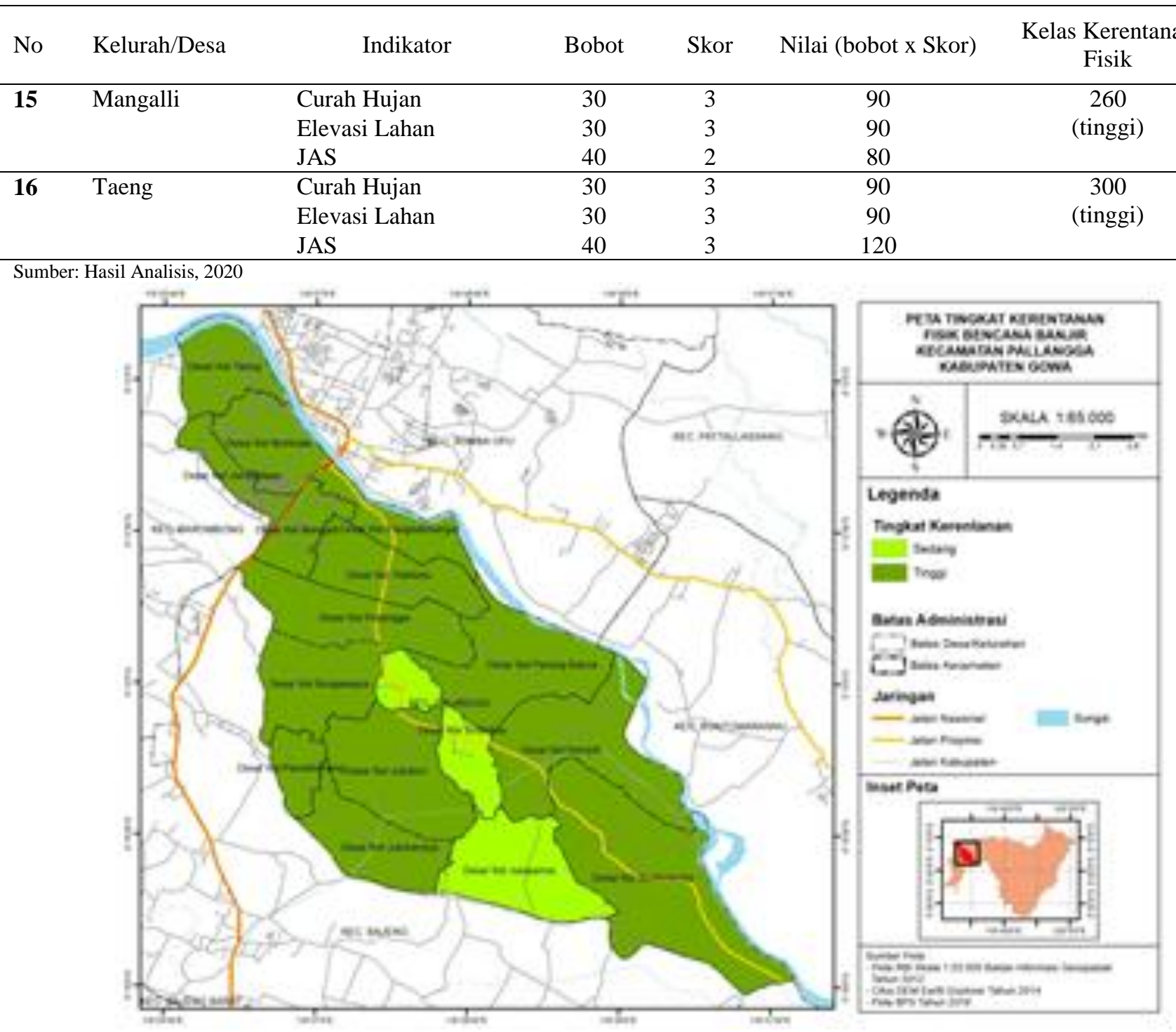

\section{Kerentanan Sosial Ekonomi}

Kerentanan sosial ekonomi menggambarkan tingkat kerapuhan masyarakat dalam mengahadapi bahaya. Penentuan kerentanan sosial ekonomi menggunakan 5

Tabel 5 Analisis Pembobotan Kerentanan Sosial Ekonomi

\begin{tabular}{|c|c|c|c|c|c|c|}
\hline No & Kelurah/Desa & Indikator & Bobot & Skor & $\begin{array}{l}\text { Nilai (Bobot } \mathrm{x} \\
\text { Skor) }\end{array}$ & $\begin{array}{l}\text { Kelas Kerentanan } \\
\text { Sosial Ekonomi }\end{array}$ \\
\hline \multirow[t]{5}{*}{1} & Jenetallasa & Kepadatan Penduduk & 60 & 3 & 180 & 240 \\
\hline & & Penduduk Miskin & 10 & 1 & 10 & (tinggi) \\
\hline & & Penduduk Wanita & 10 & 3 & 30 & \\
\hline & & Penduduk usia rentan & 10 & 1 & 10 & \\
\hline & & Penduduk cacat & 10 & 1 & 10 & \\
\hline \multirow[t]{5}{*}{2} & Tetebatu & Kepadatan Penduduk & 60 & 2 & 120 & 180 (sedang) \\
\hline & & Penduduk Miskin & 10 & 1 & 10 & \\
\hline & & Penduduk Wanita & 10 & 3 & 30 & \\
\hline & & Penduduk usia rentan & 10 & 1 & 10 & \\
\hline & & Penduduk cacat & 10 & 1 & 10 & \\
\hline \multirow[t]{5}{*}{3} & Pallangga & Kepadatan Penduduk & 60 & 2 & 120 & 190 (sedang) \\
\hline & & Penduduk Miskin & 10 & 2 & 20 & \\
\hline & & Penduduk Wanita & 10 & 3 & 30 & \\
\hline & & Penduduk usia rentan & 10 & 1 & 10 & \\
\hline & & Penduduk cacat & 10 & 1 & 10 & \\
\hline \multirow[t]{3}{*}{4} & Bungaejaya & Kepadatan Penduduk & 60 & 2 & 120 & 180 (sedang) \\
\hline & & Penduduk Miskin & 10 & 1 & 10 & \\
\hline & & Penduduk Wanita & 10 & 3 & 30 & \\
\hline
\end{tabular}

(lima) indikator penilaian yakni kepadatan penduduk, penduduk miskin, penduduk wanita, penduduk usia rentan, dan penduduk cacat. 
ISSN 2656-8705

URSJ 4(1): 01-14, Desember 2021

\begin{tabular}{|c|c|c|c|c|c|c|}
\hline No & Kelurah/Desa & Indikator & Bobot & Skor & $\begin{array}{c}\text { Nilai (Bobot x } \\
\text { Skor) }\end{array}$ & $\begin{array}{c}\text { Kelas Kerentanan } \\
\text { Sosial Ekonomi }\end{array}$ \\
\hline & & Penduduk usia rentan & 10 & 1 & 10 & \\
\hline & & Penduduk cacat & 10 & 1 & 10 & \\
\hline \multirow[t]{5}{*}{5} & Panakkukang & Kepadatan Penduduk & 60 & 3 & 180 & 250 \\
\hline & & Penduduk Miskin & 10 & 2 & 20 & (tinggi) \\
\hline & & Penduduk Wanita & 10 & 3 & 30 & \\
\hline & & Penduduk usia rentan & 10 & 1 & 10 & \\
\hline & & Penduduk cacat & 10 & 1 & 10 & \\
\hline \multirow[t]{5}{*}{6} & Julukanaya & Kepadatan Penduduk & 60 & 2 & 120 & 200 (sedang) \\
\hline & & Penduduk Miskin & 10 & 2 & 20 & \\
\hline & & Penduduk Wanita & 10 & 3 & 30 & \\
\hline & & Penduduk usia rentan & 10 & 1 & 10 & \\
\hline & & Penduduk cacat & 10 & 1 & 10 & \\
\hline \multirow[t]{5}{*}{7} & Julubori & Kepadatan Penduduk & 60 & 2 & 120 & 190 (sedang) \\
\hline & & Penduduk Miskin & 10 & 2 & 20 & \\
\hline & & Penduduk Wanita & 10 & 3 & 30 & \\
\hline & & Penduduk usia rentan & 10 & 1 & 10 & \\
\hline & & Penduduk cacat & 10 & 1 & 10 & \\
\hline \multirow[t]{5}{*}{8} & Julupamai & Kepadatan Penduduk & 60 & 1 & 60 & 130 \\
\hline & & Penduduk Miskin & 10 & 2 & 20 & (rendah) \\
\hline & & Penduduk Wanita & 10 & 3 & 30 & \\
\hline & & Penduduk usia rentan & 10 & 1 & 10 & \\
\hline & & Penduduk cacat & 10 & 1 & 10 & \\
\hline \multirow[t]{5}{*}{9} & Bontoramba & Kepadatan Penduduk & 60 & 1 & 60 & 130 \\
\hline & & Penduduk Miskin & 10 & 2 & 20 & (rendah) \\
\hline & & Penduduk Wanita & 10 & 3 & 30 & \\
\hline & & Penduduk usia rentan & 10 & 1 & 10 & \\
\hline & & Penduduk cacat & 10 & 1 & 10 & \\
\hline \multirow[t]{5}{*}{10} & Kampili & Kepadatan Penduduk & 60 & 2 & 120 & 190 (sedang) \\
\hline & & Penduduk Miskin & 10 & 2 & 20 & \\
\hline & & Penduduk Wanita & 10 & 3 & 30 & \\
\hline & & Penduduk usia rentan & 10 & 1 & 10 & \\
\hline & & Penduduk cacat & 10 & 1 & 10 & \\
\hline \multirow[t]{5}{*}{11} & Toddotoa & Kepadatan Penduduk & 60 & 2 & 120 & 190 (sedang) \\
\hline & & Penduduk Miskin & 10 & 2 & 20 & \\
\hline & & Penduduk Wanita & 10 & 3 & 30 & \\
\hline & & Penduduk usia rentan & 10 & 1 & 10 & \\
\hline & & Penduduk cacat & 10 & 1 & 10 & \\
\hline \multirow[t]{5}{*}{12} & Parangbanoa & Kepadatan Penduduk & 60 & 1 & 60 & 130 \\
\hline & & Penduduk Miskin & 10 & 2 & 20 & (rendah) \\
\hline & & Penduduk Wanita & 10 & 3 & 30 & \\
\hline & & Penduduk usia rentan & 10 & 1 & 10 & \\
\hline & & Penduduk cacat & 10 & 1 & 10 & \\
\hline \multirow[t]{5}{*}{13} & Pangkabinanga & Kepadatan Penduduk & 60 & 3 & 180 & 250 \\
\hline & & Penduduk Miskin & 10 & 2 & 20 & (tinggi) \\
\hline & & Penduduk Wanita & 10 & 3 & 30 & \\
\hline & & Penduduk usia rentan & 10 & 1 & 10 & \\
\hline & & Penduduk cacat & 10 & 1 & 10 & \\
\hline \multirow[t]{5}{*}{14} & Bontoala & Kepadatan Penduduk & 60 & 3 & 180 & 240 \\
\hline & & Penduduk Miskin & 10 & 1 & 10 & (tinggi) \\
\hline & & Penduduk Wanita & 10 & 3 & 30 & \\
\hline & & Penduduk usia rentan & 10 & 1 & 10 & \\
\hline & & Penduduk cacat & 10 & 1 & 10 & \\
\hline \multirow[t]{5}{*}{15} & Mangalli & Kepadatan Penduduk & 60 & 3 & 180 & 240 \\
\hline & & Penduduk Miskin & 10 & 1 & 10 & (tinggi) \\
\hline & & Penduduk Wanita & 10 & 3 & 30 & \\
\hline & & Penduduk usia rentan & 10 & 1 & 10 & \\
\hline & & Penduduk cacat & 10 & 1 & 10 & \\
\hline \multirow[t]{5}{*}{16} & Taeng & Kepadatan Penduduk & 60 & 3 & 180 & 250 \\
\hline & & Penduduk Miskin & 10 & 1 & 10 & (tinggi) \\
\hline & & Penduduk Wanita & 10 & 3 & 30 & \\
\hline & & Penduduk usia rentan & 10 & 2 & 20 & \\
\hline & & Penduduk cacat & 10 & 1 & 10 & \\
\hline
\end{tabular}




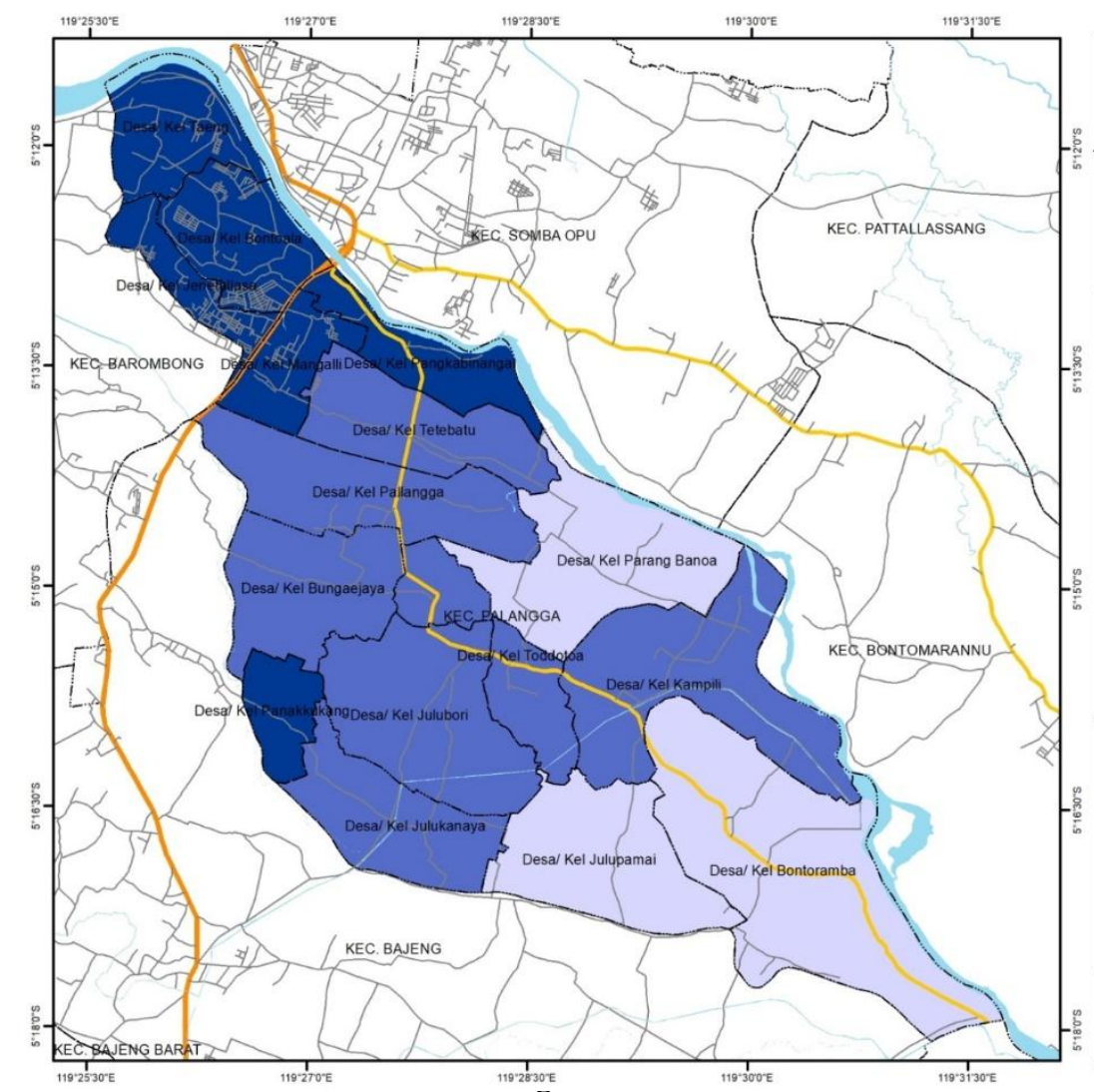

jumlah bangunan dengan luas Kelurahan (unit/ha). Hasil analisis pembobotan dapat dilihat pada Tabel 6 di bawah ini.

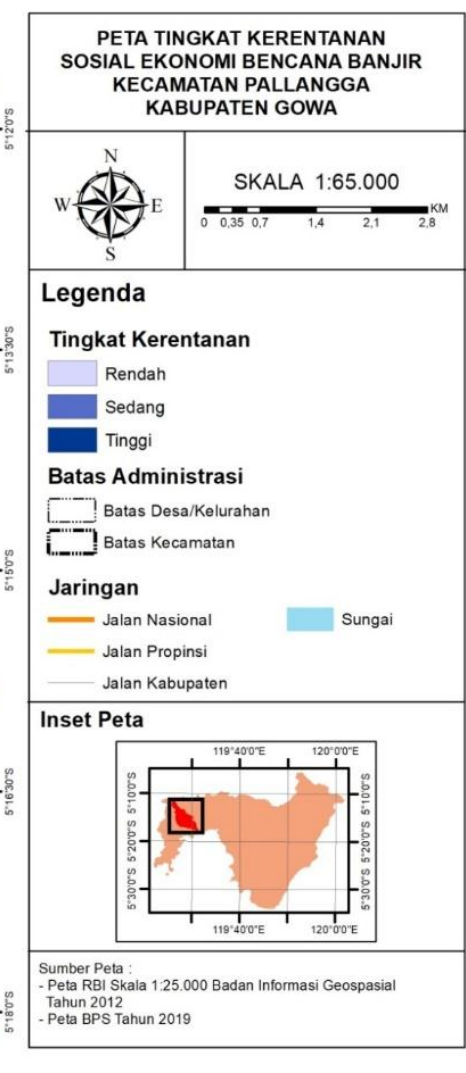

Penentuan tingkat kerentanan lingkungan menggunakan indikator penilaian kepadatan bangunan. Data kepadatan bangunan diperoleh dari perbandingan

Tabel 6 Analisis Pembobotan Kerentanan Lingkungan

\begin{tabular}{|c|c|c|c|c|c|c|}
\hline No & Kelurah/Desa & Indikator & Bobot & Skor & $\begin{array}{c}\text { Nilai } \\
\text { (Bobot x } \\
\text { Skor) }\end{array}$ & $\begin{array}{c}\text { Kelas Kerentanan } \\
\text { Lingkungan }\end{array}$ \\
\hline 1 & Jenetallasa & Kepadatan Bangunan & 100 & 2 & 200 & 200 (sedang) \\
\hline 2 & Tetebatu & Kepadatan Bangunan & 100 & 1 & 100 & 100 (rendah) \\
\hline 3 & Pallangga & Kepadatan Bangunan & 100 & 1 & 100 & 100 (rendah) \\
\hline 4 & Bungaejaya & Kepadatan Bangunan & 100 & 1 & 100 & 100 (rendah) \\
\hline 5 & Panakkukang & Kepadatan Bangunan & 100 & 1 & 100 & 100 (rendah) \\
\hline 6 & Julukanaya & Kepadatan Bangunan & 100 & 1 & 100 & 100 (rendah) \\
\hline 7 & Julubori & Kepadatan Bangunan & 100 & 1 & 100 & 100 (rendah) \\
\hline 8 & Julupamai & Kepadatan Bangunan & 100 & 1 & 100 & 100 (rendah) \\
\hline 9 & Bontoramba & Kepadatan Bangunan & 100 & 1 & 100 & 100 (rendah) \\
\hline 10 & Kampili & Kepadatan Bangunan & 100 & 1 & 100 & 100 (rendah) \\
\hline 11 & Toddotoa & Kepadatan Bangunan & 100 & 1 & 100 & 100 (rendah) \\
\hline 12 & Parangbanoa & Kepadatan Bangunan & 100 & 1 & 100 & 100 (rendah) \\
\hline 13 & Pangkabinanga & Kepadatan Bangunan & 100 & 1 & 100 & 100 (rendah) \\
\hline 14 & Bontoala & Kepadatan Bangunan & 100 & 1 & 100 & 100 (rendah) \\
\hline 15 & Mangalli & Kepadatan Bangunan & 100 & 1 & 100 & 100 (rendah) \\
\hline 16 & Taeng & Kepadatan Bangunan & 100 & 1 & 100 & 100 (rendah) \\
\hline
\end{tabular}




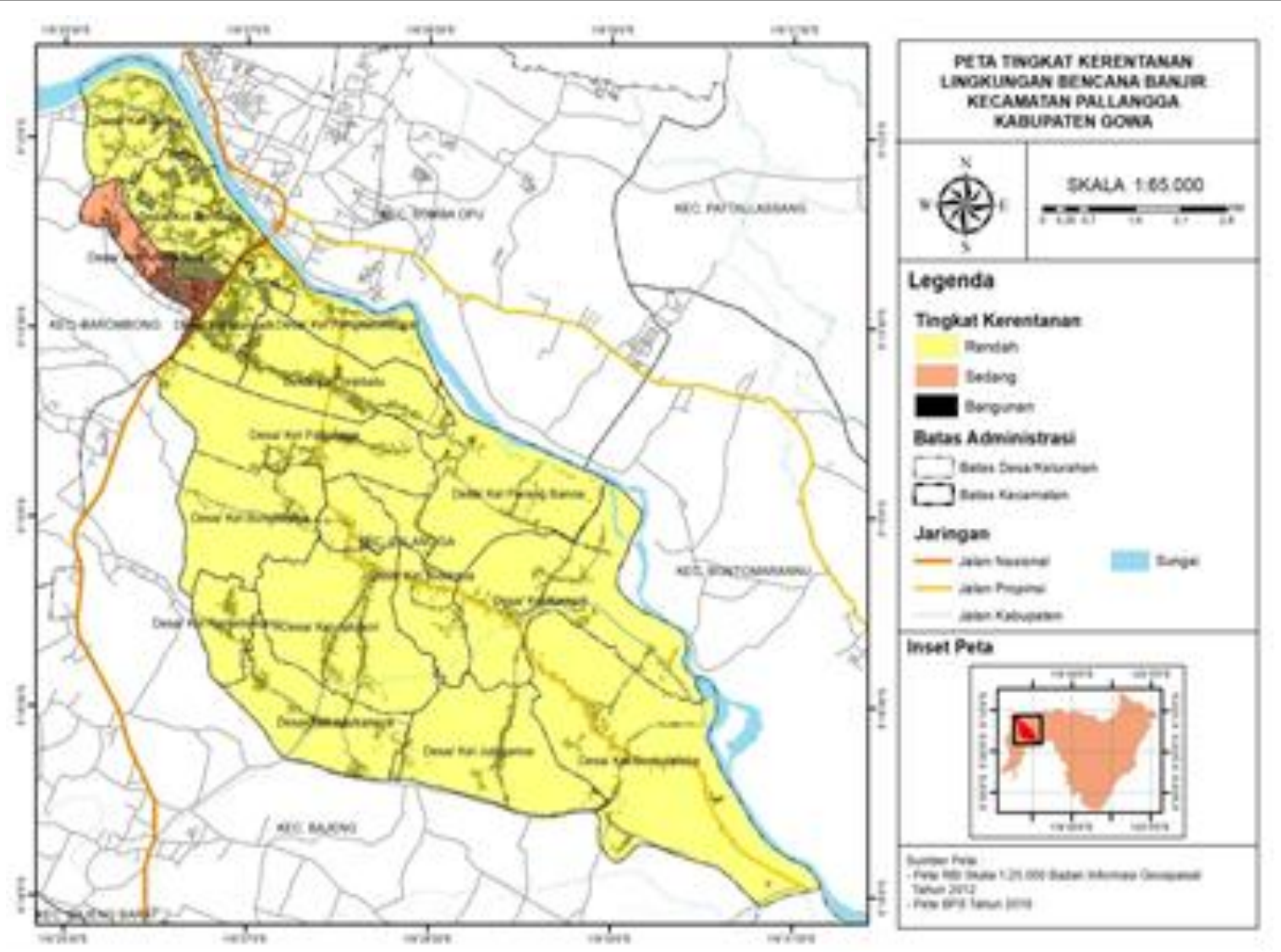

Gambar. 4 Peta Tingkat Kerentanan Lingkungan Kecamatan Pallangga

Selanjutnya untuk mengetahui persebaran kerentanan banjir diperoleh dengan mengoverlay semua variabelvariabel kerentanan banjir. Nilai kerentanan yang diperoleh dari masing-masing kerentanan fisik, sosial ekonomi dan lingkungan dijumlahkan dan dibagi menjadi tiga klasifikasi rentan tinggi, rentan sedang dan rentan rendah.

Tabel 7 Analisis tingkat kerentanan bencana banjir di kecematan Pallangga

\begin{tabular}{llcccc}
\hline No & Kelurah/Desa & $\begin{array}{c}\text { Nilai } \\
\text { Kerentanan } \\
\text { Fisik }\end{array}$ & $\begin{array}{c}\text { Nilai Kerentanan } \\
\text { Sosial Ekonomi }\end{array}$ & $\begin{array}{c}\text { Nilai Kerentanan } \\
\text { Lingkungan }\end{array}$ & $\begin{array}{c}\text { Kelas Rentan } \\
\text { Banjir }\end{array}$ \\
\hline 1 & Jenetallasa & 300 & 240 & 200 & 740 (tinggi) \\
2 & Tetebatu & 300 & 180 & 100 & 580 (sedang) \\
3 & Pallangga & 260 & 190 & 100 & 550 (sedang) \\
4 & Bungaejaya & 260 & 180 & 100 & 540 (sedang) \\
5 & Panakkukang & 260 & 250 & 100 & 610 (sedang) \\
6 & Julukanaya & 300 & 200 & 100 & 600 (sedang) \\
7 & Julubori & 260 & 190 & 100 & 550 (sedang) \\
8 & Julupamai & 190 & 130 & 100 & 420 (rendah) \\
9 & Bontoramba & 270 & 130 & 100 & 500 (rendah) \\
10 & Kampili & 300 & 190 & 100 & 590 (sedang) \\
11 & Toddotoa & 220 & 190 & 100 & 510 (rendah) \\
12 & Parangbanoa & 300 & 130 & 100 & 530 (sedang) \\
13 & Pangkabinanga & 300 & 250 & 100 & 650 (tinggi) \\
14 & Bontoala & 300 & 240 & 100 & 640 (tinggi) \\
15 & Mangalli & 260 & 240 & 100 & 640 (sedang) \\
16 & Taeng & 300 & 240 & &
\end{tabular}

Berdasarkan tabel. 7 dihasilkan nilai terendah 420 dan nilai tertinggi 740 . Untuk pembuatan interval kelas dalam penelitian ini yaitu menggunakan rumus Kingma menghasilkan value nilai interval kelas 106. Nilai ini mengartikan bahwa dalam setiap tingkatan rentan banjir akan memiliki anggota nilai interval yang rentangnya adalah 106.

Desa Jenetallasa, Kelurahan Pangkabinanga, Desa Bontoala dan Desa Taeng menunjukkan rentan tinggi terhadap banjir dengan nilai kelas klasifikasi $634-740$. Sedangkan Kelurahan Tetebatu, Pallangga, Bungaejaya, Panakkukang, Julukanaya, Julubori, Kampili, Parangbanoa, dan Kelurahan Mangalli menunjukkan rentan sedang terhadap banjir dengan kelas klasifikasi 527 - 633, dan Kelurahan Julupamai, Desa Bontoramba, dan Toddotoa menunjukkan kelas rentan rendah dengan nilai kelas kalsifikasi 420 - 526 . 


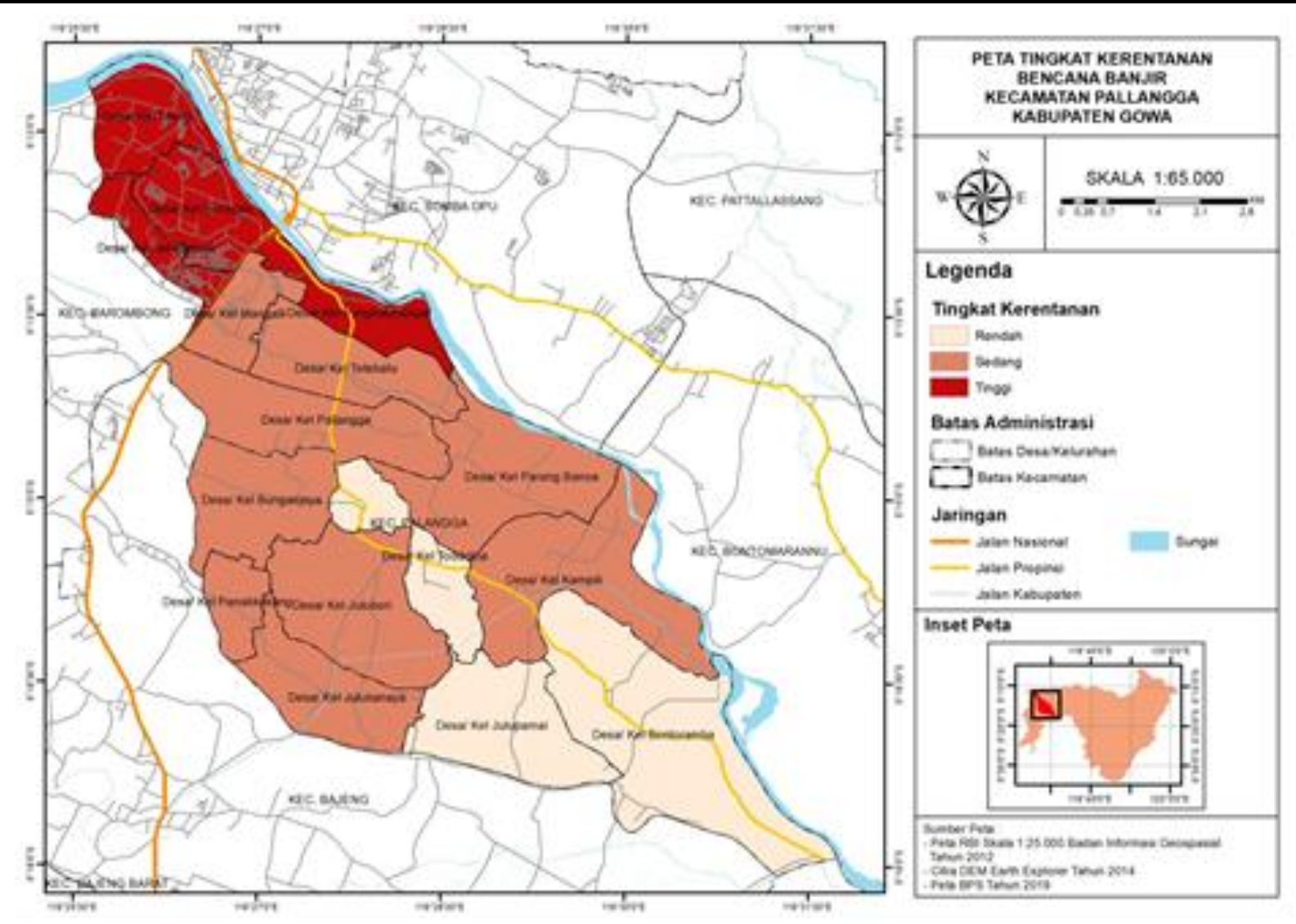

Gambar. 5 Peta Tingkat Kerentanan Bencana Banjir di Kecamatan Pallangga

\section{Adaptasi Masyarakat}

Dari hasil analisis kerentanan bencana banjir di Kecamatan Pallangga, 4 Desa/Kelurahan menunjukkan rentan tinggi terhadap bencana banjir yaitu Kelurahan Pangkabinanga, Desa Bontoala, Desa Taeng, dan Desa Jenetallasa. Bentuk adaptasi masyarakat merupakan salah satu kajian kerentanan yang diartikan sebagai karakteristik dan situasi sebuah masyarakat, sistem, atau aset yang mempengaruhi mudahnya terkena dampak merugikan dari sebuah bahaya atau bencana. Bentuk adaptasi yang dilakukan oleh masyarakat bervariasi sesuai dengan kondisi kerentanan kapasitas/ pengetahuan masyarakat dan kondisi perekonomian.

\section{Karakteristik Masyarakat}

Padatnya penduduk serta pemukiman atau perumahan - perumahan yang terbangun merupakan faktor utama yang mempengaruhi tingginya kerentanan banjir di Desa Jenetallasa. Desa Jenetallasa merupakan desa dengan kepadatan penduduk dan kepadatan bangunan paling tinggi di antara Desa/Kelurahan yang ada di Kecamatan Pallangga dengan kepadatan penduduk $164 \mathrm{jiwa} / \mathrm{ha}$ dan kepadatan bangunan 20 unit/ha. Masyarakat yang bermukim di perumahan yang ada di Desa Jenetallasa sebagian besar bukan penduduk asli dan merupakan dari kelas menengah dan tinggi dengan besar pendapatan rata-rata per bulan Rp. 1.500.000 - Rp. 2.500.000 untuk golongan sedang dan golongan tinggi berpenghasilan rata-rata per bulan $\mathrm{Rp}$. 2.500.000 - Rp. 3.500.000.

Kelurahan Pangkabinanga merupakan titik terparah terjadinya banjir bandang yang terjadi pada awal tahun 2019. Kelurahan Pangkabinanga yang berbatasan langsung dengan sungai Jeneberang merupakan faktor utama rentannya terhadap bencana banjir. Lingkungan Pangkabinanga, Kampung Jangka dan Lingkungan
Mappala merupakan 3 lingkungan yang berada di kawasan sempadan sungai. Penduduk Kelurahan pangkabinanga kebanyakan bergerak pada sektor pertanian dan buruh. Masyarakat yang bermukim di kawasan sempadan sungai memiliki tingkat pendapatan rendah sampai menengah dengan berpenghasilan rata-rata per bulan Rp. $1.500 .000-$ Rp. 2.500.000 untuk kelas menengah dan < Rp. 1.500.000 untuk pendapatan kelas rendah.

Sama halnya dengan Kelurahan Pangkabinanga, Desa Bontoala dan Desa Taeng juga secara administratif berbatasan langsung dengan Sungai Jeneberang dan merupakan daerah dengan kerentanan tinggi terhadap bencana banjir. Mata pencaharian masyarakat di Desa Bontoala dan Desa Taeng ada yang sebagai petani pegawai/PNS dan wiraswasta atau pedagang. Permukiman di Desa Bontoala dan Desa Taeng memiliki kegiatan yang berbeda-beda. Banyak penduduk membuka usaha di rumah atau pedagang non formal. fungsi dari bangunan sudah berubah menjadi campuran antara hunian dan tempat usaha. Kegiatan masyarakat di Desa Bontoala dan Desa Taeng ini sangat bervariasi diantaranya ada yang melakukan kegiatan industri di rumah, berjualan dengan menggunakan warung, membuka warung makan, kios pulsa serta toko bangunan.

\section{Dampak Bencana}

Dampak bencana banjir yang terjadi banyak yang kehilangan dan kerusakan harta benda, dan berbagai macam peralatan rumah karena banjir masuk ke dalam rumah. Yang paling berbahaya yaitu jika bencana banjir sampai merenggut korban jiwa. Kerugian Non Material merupakan bentuk kerugian yang wujudnya tidak nampak secara fisik, namun dampaknya terasa mengganggu bagi masyarakat, seperti: dampak psikologis, dan menyebarnya wabah penyakit. Berangkat dari berbagai masalah seperti itu menyebabkan timbulnya rasa trauma. 
Permukiman penduduk di Kelurahan Pallangga saat banjir melanda, beberapa jenis penyakit yang diderita oleh masyarakat antara lain penyakit diare, leptospirosis, dan gatal-gatal pada kulit akibat lingkungan yang tidak bersih serta penyakit malaria akibat terbentuknya genangan air yang mengundang nyamuk malaria. Hasil pembahasan dari penelitian yang diperoleh tentang kerugian material dan non material akibat dampak banjir adalah pada umumnya banjir memiliki berbagai akibat dan dampak negatif yang secara langsung maupun tidak langsung berpengaruh bagi manusia. Kerugian yang timbul akibat banjir dapat dikomulasikan dari hilangnya fungsi lahan dan bangunan, rusaknya harta benda sarana prasarana lingkungan, terhambatnya akses transportasi, dan besarnya biaya tambahan yang harus dikeluarkan.

Di Desa Taeng, telah banyak dibangun perumahan baru dengan merubah bentuk muka tanah dari lahan pertanian atau perkebunan yang merupakan wilayah rendah dan berdekatan dengan tanggul sungai Jeneberang yang menjadi kawasan perumahan, akibatnya setiap musim penghujan datang selalu dikepung banjir. Salah satunya warga perumahan Cakra Hidayat Regency Desa Taeng yang merasa dirugikan oleh pihak pengembang perumahan yang menjanjikan perumahan tersebut bebas banjir. Permasalahan dengan pihak pengembang perumahan bukan pertama kali terjadi di Desa Taeng. Pada tahun 2013 ratusan rumah di kompleks perumahan BTN Aura dan Mutiara Zahrah Permai Desa Taeng terendam banjir. Akibat banjir warga mengaku kesal yang merasa ditipu karena promosi perumahan bebas banjir dan meminta untuk pengembang bertanggung jawab (tribun-timur.com). Pengendalian pembangunan seharusnya dilakukan untuk permukiman yang rentan terhadap banjir, dalam himbauan atau mencegah sejak awal bagi pengembang yang mau mengembangkan di wilayah tersebut, karena hal ini berdampak kepada masyarakat tetapi secara teknisnya disesuaikan dengan dinas teknis yang berkepentingan. Pengendalian pembangunan di daerah beresiko baik dengan aturan tata ruang, ataupun perketatan izin dapat bermanfaat dalam mengurangi risiko wilayah terdampak, dikarenakan pembatasan pembangunan untuk menjaga keberlanjutan wilayah.

\section{Pola Adaptasi Masyarakat}

Di dalam adaptasi terdapat pola-pola menyesuaikan diri dengan lingkungan. Pola adaptasi yang ditemukan dalam masyrakat berbeda-beda pada setiap wilayah dan jarak dari sungai serta karakteristik masyarakat. Banyak masyarakat memilih untuk tetap bertahan mendiami rumah mereka meski kerap kali terkena banjir. Beragam hal menjadi pertimbangan mereka untuk tidak pindah. karena rumah sendiri, faktor finansial, atau bahkan karena sudah terbiasa menghadapi banjir. Akan tetapi, tidak semua masyarakat sepenuhnya untuk bertahan, bagi pemilik rumah yang mendiami hunian yang sering langganan banjir apabila hujan lebat ada beberapa masyarakat yang mempertimbangkan sejumlah dampak negatif menetap di rumah rawan banjir. Sehingga dari beberapa masyarakat sudah merencanakan untuk pindah rumah. Meski pindah rumah bukan perkara mudah, namun kepekaan masyarakat untuk bertindak dan memperimbangkan kenyamanan masih sebatas rencana dari pada harus pasrah tiap kali hujan deras dan harus menangani banjir.
Pola adaptasi masyarakat pada wilayah penelitian adalah dengan memperkuat dan meninggikan pondasi rumah, menaruh benda berharga (menaikkan ke tempat yang lebih tinggi), Bentuk adaptasi masyarakat di kelurahan Jenetallasa yang memiliki pengetahuan akan bencana bahaya banjir dan memiliki pendapatan yang mencukupi, memilih memperbaiki rumah dan meninggikan pondasi rumah. Sedangkan masyarakat dengan kemampuan finansial rendah, masyarakat akan melakukan peninggian rumah dengan bertahap dan hanya bagian-bagia tertentu rumah yang ditinggikan seperti kamar, dapur dan kamar mandi.

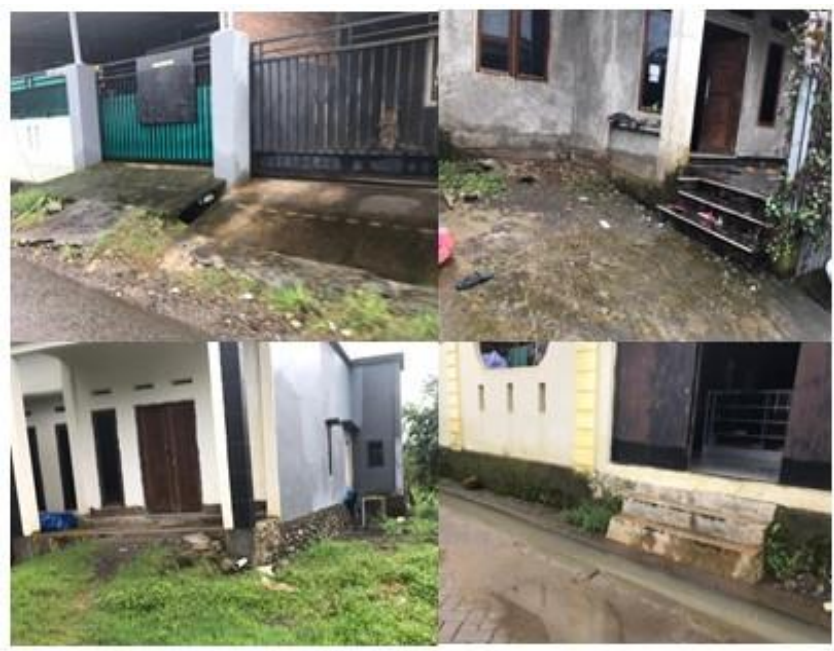

Gambar 6 Rumah Penduduk di Desa Jenetallasa dengan Meninggikan Pondasi Rumah

Pihak Desa/Kelurahan menghimbau masyarakat untuk selalu berhati-hati dan sigap dalam upaya-upaya pencegahan. Membangun rumah lebih tinggi merupakan opsi apabila terjadinya banjir air tidak langsung masuk dalam rumah, serta harta benda sudah diamankan sehingga tidak banyak kerugian yang didapat karena warga sudah beradaptasi dalam kesiapsiagaan kejadian banjir setiap tahunnya.

Bentuk adaptasi masyarakat Desa Jenetallasa yang berada di kawasan yang jauh dari sungai berbeda dengan bentuk adaptasi yang berada dekat dengan sungai dan kanal. Bentuk adaptasi masyarakat yang berada dekat sungai dan kanal memiliki rumah dengan material kayu dan rumah panggung. Masyarakat yang bermukim di daerah dekat sungai umumnya merupakan masyarakat kelas rendah dengan penghaasilan rata-rata $<$ Rp. 1.500.000.

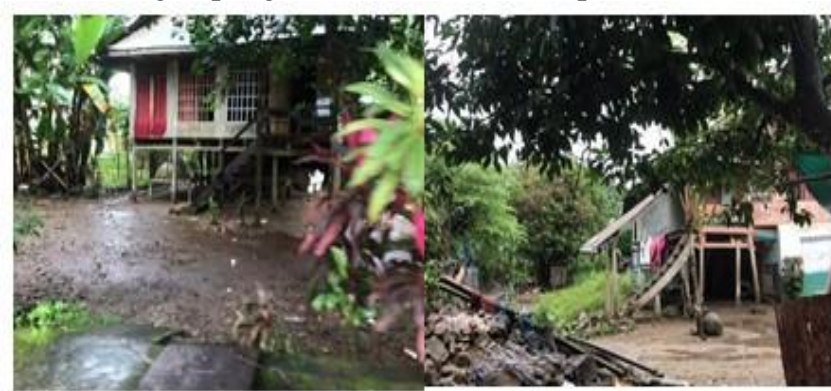

Gambar 7 Rumah panggung di Desa Jenetallasa

Bentuk adaptasi kegiatan yang dilakukan masyarakat di Desa Bontoala dan Taeng untuk meminimalisir kerugian yaitu memasang penyangga dibawah barang elektronik dengan menggunakan kayu, besi, semen dan bata. 
Masyarakat membuat penyangga untuk menopang barangbarang elektronik agar tidak terendam banjir, tetapi banyak masyarakat yang menggunakan kayu sebagai bahan utama pembuat penyangga. Kondisi pada jaringan drainase meliputi kondisi drainase yang sempit, dangkal, dan tidak lancar sangat mempengaruhi fenomena banjir disuatu wilayah.

Apabila memasuki musim penghujan Masyarakat di lokasi penelitian melakukan adaptasi membersihkan darinase yang ada di lingkungan sebelum datangnya musim penghujan, selokan air yang penuh dengan endapan tanah dan sampah yang dapat menyumbat saluran air yang ada di rumah-rumah warga. Masyarakat yang ada BTN Aura Permai Desa Bontoala sering bergotong royong melakukan kerja bakti membenahi saluran drainase untuk menghindari masalah banjir. Kerja bakti ini dilakukan warga secara swadaya dan sebagai bentuk kepedulian terhadap lingkungannya.

\section{Upaya Mitigasi dan Adaptasi}

Mitigasi bencana banjir adalah serangkaian upaya yang dilakukan dalam rangka meminimalisir risiko yang ditimbulkan akibat bencana banjir. UU No. 24 Tahun 2007 tentang penanggulangan bencana menyatakan bahwa mitigasi adalah serangkaian upaya untuk menguraingi risiko bencana, baik melalui pembangunan fisik maupun penyadaran dan peningkatan kemampuan menghadapi ancaman bencana. Pemerintah Kabupaten Gowa menetapkan Peraturan Daerah Nomor 01 Tahun 2013 tentang Penanggulangan Bencana Daerah Kabuapten Gowa, yang mengatur pelaksanaan penanggulangan bencana mulai dari tahap pra bencana, tanggap darurat bencana hingga tahap pasca bencana. Penyelenggaraan Penanggulangan Bencana di Kabupaten Gowa dilaksanakan oleh Badan Penanggulangan Bencana Daerah (BPBD) sebagai leading sector kebencanaan di wilayah. BPBD melaksanakan mitigasi bencana banjir secara non fisik/ struktural dengan melibatkan stakeholders lain yaitu dengan sektor sipil, sektor private dan sektor publik. Upaya mitigasi dan adaptasi merupakan alternatif strategi yang dapat dilakukan untuk mengantisipasi potensi kerentanan. Dalam hal penanggulangan bencana Upaya-upaya mitigasi banjir dapat dilakukan sebelum, selama dan sesudah terjadinya bencana banjir.

Secara umum strategi adaptasi yang dapat dilakukan untuk mengatasi kerentanan bencana ada dua bentuk, yakni mitigasi struktural dan mitigasi non struktural. Tindakan mitigasi struktural dapat dilakukan meliputi normalisasi sungai, pembuatan bendungan dan perbaikan drainase. Mitigasi non struktural dapat dilakukan melalui cara zonasi potensi rawan dan risiko bencana banjir. Memberikan sosialisasi dan peringatan dini upaya penyelamatan diri dan regulasi kebijakan pemanfaatan ruang pada zona rawan dan risiko bencana banjir. Berdasarkan hasil penilaian kerentanan yang telah dilakukan, teridentifikasi bahwa Kecamatan Pallangga memiliki tiga tingkat kerentanan terhadap bencana banjir. Untuk mengantisipasi dampak yang mungkin terjadi akibat bencana banjir, adapun upaya mitigasi yang dapat diupayakan yakni:

1. Perencanaan Pengelolaan Kawasan Sempadan Sungai

Kawasan sempadan sungai menjadi kawasan yang cukup penting untuk diperhatikan dan dikelola, khususnya berkaitan dengan potensi bencana banjir. Hal itu berkaitan dengan pemanfaatan kawasan sempadan sungai yang tidak sesuai dengan peruntukanya yaitu sebagai permukiman, tempat usaha bahkan industri maupun peternakan. Pemanfaatan tersebut khususnya untuk permukiman tentu akan meningkatkan kerentanan, sehingga ketika terjadi banjir maka potensi kerugian baik jiwa maupun material akan meningkat. Perubahan pemanfaatan lahan sempadan sungai yang terjadi di Kelurahan Pangkabinanga Kabupaten Gowa cenderung diakibatkan oleh peningkatan penduduk setiap tahunnya, dimana mereka membutuhkan lahan untuk membangun tempat tinggal serta melakukan aktifitas lainnya, sementara lahan yang tersedia tetap sehingga lahan yang ada seperti pertanian, perkebunan dan lain-lain dijadikan daerah terbangun.

Konsepsi pemanfaatan lahan kawasan sempadan sungai Jeneberang di Kelurahan Pangkabinanga akan diarahkan untuk penetapan kawasan lindung. Berdasarkan kriteria kesesuaian penggunaan lahan sempadan sungai berdasrkan peraturan zonasi arahan fungsi pemanfaatan lahan sempadan sungai sekurang-kurangnya 100 meter dari kiri sungai besar.

\section{Pemeliharaan Kanal, Saluran dan Sistem Drainase, Serta Perencanaan Saluran Drainase}

Pemeliharaan kanal dilakukan dengan pengerukan untuk mencegah luapan saat hujan dengan intensitas tinggi. Sama halnya dengan saluran dan sistem drainase dengan melakukan pengerukan sampah yang menyebabkan penyumpatan saluran., begitu juga dengan kanal yang secara rutin harus dilakukan pengerukan guna mengantisipasi banjir. Proses normalisasi sungai nantinya dilakukan dengan menggunakan peralatan berat yang diterapkan untuk saluran drainase primer/ kanal maupun pada sungai. Alat berat yang biasa digunakan adalah backhoe, clampshell, dan dump truck.

Upaya perbaikan drainase dilakukan dengan perbaikan menyeluruh sistem drainase dengan memperhatikan interkoneksi saluran dan arah aliran air, sehingga sistem drainase dapat berfungsi optimal untuk mengalirkan air hingga ke muara saluran. Upaya perbaikan tersebut dilakukan dengan cara meningkatkan kualitas system drainase. Dalam memperbaiki drainase yang berstatus drainase primer, dilakukan oleh Dinas PU Provinsi Sulsel, sedangkan drainase sekunder dan tersier dilakukan oleh Dinas PU dan Tata Ruang Kabupaten Gowa.

Beberapa titik di lokasi tidak mempunyai drainase sehingga pengembangan sistem drainase baru dilakukan dengan membuat drainase yang belum terbangun. Pembuatan drainase sangat diharapkan untuk dilakukan sehingga air bisa dialirkan dan tidak menyebabkan genangan serta air tidak masuk ke rumah masyarakat. Dalam pembangunan tersebut harus memperhatikan arah aliran dan topografi wilayah, sehingga air dapat mengalir menggunakan gaya gravitasi bumi. Selain itu, untuk wilayah dengan kepadatan bangunan yang tinggi, dapat dikembangkan sistem drainase tertutup menggunakan box culvert (ukuran menyesuaikan kondisi wilayah) yang dapat ditempatkan di sisi jalan, ataupun tepat di bawah jalan, sehingga tidak menggunakan banyak tempat dalam pembangunannya.

\section{Peningkatan Elevasi Bangunan dengan \\ Penggalakan Rumah Panggung}

Meningkatkan elevasi bangunan dengan rekayasa konstruksi dalam bentuk rumah panggung, upaya ini dilakukan apabila ingin dilakukan pengembangan di 
daerah cekungan dan dataran rawa, dimana level genangan saat terjadi banjir tergolong tinggi, serta masyarakat yang berada dekat dengan aliran sungai, untuk tetap dapat dikembangkan digunakan rekayasa konstruksi dalam bentuk rumah panggung. Karena kawasan yang berada pada rentan tinggi di Kecamtan Pallangga merupakan bagian dari kawasan perkotaan, rumah panggung dapat dimodernisasi menyesuaikan arsitektural zaman sekarang dengan penerapan tiang beton sebagai penopang rumah menggantikan kayu yang lebih mudah lapuk.

Bentuk penyelesaian untuk pemanfaatan daerah rendah juga dengan menggunakan sistem timbunan (land filling). Sistem timbunan merupakan cara pemanfaatan dataran rendah dengan cara menimbun lahan dengan material tanah sehingga mencapai elevasi aman di atas permukaan air sungai tertinggi. Sehingga demikian daerah yang ditimbun menjadi aman dari pengaruh banjir.

\section{Pembuatan jalur evakuasi, sistem peringatan dini} serta simulasi bencana

Penentuan jalur evakuasi harus beriringan dengan penentuan titik kumpul sementara maupun titik pengungsian, dengan tujuan agar alur proses evakuasi dapat berlangsung dengan efektif sehingga potensi jatuhnya korban dapat diminimalisasi. Membuat jalur evakuasi dengan cara mempertimbangkan daerah risiko banjir, ketinggian wilayah, akses dalam bentuk prasarana jalan, serta lokasi pengungsian yang direncanakan. Jalur evakuasi dibuat dengan mengembangkan petunjuk-petunjuk menuju lokasi pengungsian. Penentuan jalur evakuasi, titik kumpul dan titik pengungsian harus melalui kajian agar mendapatkan jalur dengan jarak tempuh terdekat dan waktu tempuh tersingkat untuk mencapai titik kumpul yang aman.

Selain itu, sosialisasi tentang jalur evakuasi juga harus dilakukan kepada masyarakat sehingga masyarakat mengetahui dan memahami fungsi dari jalur evakuasi tersebut. Jalur evakuasi dapat ditandai petunjuk arah untuk mempermudah proses evakuasi. Penentuan jalur evakuasi dan titik kumpul dapat dilakukan oleh pemerintah dengan melibatkan masyarakat. Sistem peringatan dini cenderung identik dengan peringatan yang dikirimkan oleh alat-alat yang canggih yang dimiliki oleh badan yang berwenang terkait bencana yaitu BPBD Kabupaten Gowa. Namun, sistem tersebut akan lebih efektif dengan penyediaan peralatan yang dapat dipahami oleh masyarakat luas maupun diintegrasikan dengan kearifan lokal masyarakat. Kearifan lokal yang dimaksud adalah bentuk-bentuk komunikasi untuk saling memperingatkan sebelum bencana melanda.

Simulasi bencana di DAS Jeneberang serta upaya tanggap darurat bencana banjir terus dilakukan oleh pemerintah Kabupaten Gowa, tetapi edukasi dan simulasi belum secara intensif dilakukan di semua kelurahan/Desa yang rentan banjir. Dalam melakukan pengedukasian masyarakat, pihak yang berkepentingan yaitu pemerintah melalui BPBD Kabupaten Gowa di tiap tingkatan administrasi yang lebih kecil yaitu tingkat kelurahan di wilayah Kecamatan Pallangga, sehingga setiap masyarakat dapat memahami dengan baik serta melibatkan seluruh tingkat masyarkat khususnya masyarakat yang termasuk golongan rentan dengan melibatkan lansia dan anak-anak, wanita dan penduduk cacat.. Oleh karena, pelaksanaan simulasi menjadi penting dilakukan untuk membangun masyarakat tangguh bencana.

\section{Penegakan Pengendalian Pemanfaatan Ruang dengan Zoning Regulation serta Instrumen Pengendalian Ruang}

Penegakan pemanfaatan ruang di wilayah Kecamatan Pallangga dilakukan dengan penerapan pengendalian pemanfaatan ruang dengan zoning regulation untuk mengawal pemanfaatan ruang di wilayah Kecamatan Pallangga. Hal tersebut dikarenakan zoning regulation membahasa secara mikro zonasi kawasan, sehingga dapat menghindari pemanfaatan ruang yang tidak sesuai dengan kondisi wilayah. Dalam rencana zonasi tersebut harus didasarkan pada poin-poin utama di bawah ini, antara lain:

a. Wilayah RTH atau resapan air di Kecamatan Pallangga tidak boleh dikembangkan menjadi kawasan terbangun untuk tetap mempertahankan fungsi RTH sebagai daerah resapan.

b. Wilayah persawahan yang akan dikonversi menjadi kawasan terbangun hanya dapat dilakukan apabila wilayah persawahan tersebut tidak berada di daerah rendah (landai/cekung) dan tidak lagi berproduksi (hasil tani) secara optimal, selain kaidah-kaidah lingkungan lainnya.

Upaya pengendalian pembangunan merupakan salah satu upaya yang berhasil untuk menghindarkan kerusakan terhadap suatu wilayah yang beresiko. Bentuk yang ditekankan adalah dengan penegakan aturan terhadap zonasi tata ruang, pengimplementasian insentif dan disinsentif, atau pencegahan dari awal untuk tidak membangun di wilayah tersebut.

Penegakan hukum perizinan pembangunan dalam penyesuaian intensitas kerapatan bangunan dilakukan dengan cara pengawasan yang terdiri dari pemantauan dan evaluasi. Dalam proses pemantauan dilakukan pemantauan kesesuaian fisik bangunan, sedangkan evaluasi dilakukan meninjau hasil pemantauan dengan dokumen perizinan bangunan tersebut. Hal utama yang menjadi bahan pengawasan adalah KDH (koefisien dasar hijau) dalam satu kaveling. Pelaksanaan upaya ini dilakukan oleh Dinas PU dan Tata Ruang Kabupaten Gowa yang merupakan dinas teknis terkait dalam hal perizinan pembangunan. Penegakan hukum perizinan pembangunan ini diimplementasikan ke seluruh wilayah Kecamatan Pallangga, khususnya untuk pengembangan baru.

\section{Optimalisasi Kegiatan Penyuluhan dan \\ Peningkatan Pemahaman Masyarakat terhadap Bencana Banjir secara Berkelanjutan}

Sosialisasi terkait bencana banjir dilakukan dengan penyuluhan secara berkala untuk masyarakat di Kecamatan Pallangga. Memberikan informasi secara lisan dan tertulis mengenai kegiatan penanggulangan bencana guna peningkatan pengetahuan masyarakat. Pihak pemerintah melalui BPBD Kabupaten Gowa sebagai pihak yang berkepentingan, melakukan pengedukasian masyarakat di tiap tingkatan administrasi yang lebih kecil yaitu tingkat kelurahan di wilayah Kecamatan Pallangga, sehingga setiap masyarakat dapat memahami dengan baik mengenai hal-hal berikut :

a. Penyuluhan mengenai bagaimana cara menghindari bahaya banjir, sehingga kerugian yang ditimbulkan tidak terlalu besar. 
b. Pengembangan kesadaran lingkungan masyarakat dengan melakukan sosialisasi mengenai larangan membuang sampah dan lain sebagainya di sungai/saluran.

c. Peningkatan kesadaran masyarakat terkait larangan aturan aktivitas di daerah alur sungai, seperti tinggal di bantaran sungai.

d. Peningkatan kesadaran masyarakat bahwa tinggal di daerah bawah atau daerah dataran banjir, perlu menaati peraturan-peraturan dan mematuhi larangan yang ada.

Hasil akhir yang diharapkan adalah terbentuknya kelompok siap siaga bencana di Kecamatan Pallangga serta Katana (Keluarga Tangguh Bencana) masyarakat bisa tanggap dan tangguh dalam menghadapi bencana serta evakuasi mandiri yang perlu di dalam sebuah keluarga.

\section{Kesimpulan dan Saran}

Tingkat kerentanan terhadap bencana banjir di Kecamatan pallangga terdiri dari tiga klasifikasi yaitu kelas rentan rendah, rentan sedang dan rentan tinggi. Banjir di Kecamatan Pallangga Kabupaten Gowa menyebabkan dampak yang cukup besar terhadap masyarakat dan wilayah. Namun adaptasi eksisting yang dilakukan belum efektif untuk mengurangi kerentanan wilayah terhadap banjir yang terjadi di Kecamatan Pallangga, dikarenakan operasional kegiatan adaptasi yang lambat dan tidak terpadu serta pengetahuan masyarakat terhadap bencana. Berdasarkan kondisi tersebut, arahan mitigasi yang dihasilkan mempertimbangkan faktor-faktor kerentanan banjir yang berpengaruh di Kecamatan Pallangga.

Pentingnya kesadaran masyarakat dalam menghadapi bencana banjir diharapkan untuk memaksimalkan sosialisasi yang diberikan kepada masyarakat, agar masyarakat khususnya yang berada di wilayah rentan banjir lebih sadar lagi akan pentingnya penanggulangan banjir menjadi lebih dan menghasilkan manajemen bencana yang baik sehingga daapt menekan kerugiadan kerusakan yang terjadi akibat bencana banjir.

\section{Daftar Pustaka}

Badan Nasional Penanggulangan Bencana, Pedoman Umum Desa/Kelurahan Tangguh Bencana, Jakarta: BNPB, 2012.

Badan Nasional Penanggulangan Bencana, Bencana Alam Kabupaten Gowa, 2019.

Badan Penanggulangan Bencana Daerah, Data Bencana/Kejadian KabupatenGowa, Gowa: BPBD, 2019.

Danim, Sudarwan. 2002. Menjadi Peneliti Kualitatif, Bandung: Pustaka Setia.

Itsukushima, R. (2018). Countermeasures against floods that exceed design levels based on topographical and historical analyses of the September 2015 Kinu River flooding. Journal of Hydrology: Regional Studies, 19, 211-223.

Jamrussri, S., \& Toda, Y. (2017). Simulating past severe flood events to evaluate the effectiveness of nonstructural flood countermeasures in the upper Chao Phraya River Basin, Thailand. Journal of Hydrology: Regional Studies, 10, 82-94.
Kai, W., Deyi, C., \& Zhaohui, Y. (2016 ). Flood control and management for the transitional Huaihe River in China. Dalam P. Engineering (Penyunt.), 12th International Conference on Hydroinformatics, HIC 2016.154, hal. 703 -709. Elsevier Ltd.

Kiedrzynska, E., Kiedrzynski, M., \& Zalewski, M. (2014). Sustainable floodplain management for flood prevention and water quality improvement. Journal of Natural Hazards, 76, 955-977.

Kodoatie Robert J, Sugiyanto. 2002. Banjir Beberapa Penyebab dan Metode Pengendaliannya Dalam Perspektif Lingkungan. Yogyakarta: Pustaka Pelajar.

Rezende, O. M., de Franco, A. B., de Oliveira,A. K., Jacob, A. C., \& Miguez, M. G. (2019). A framework to introduce urban flood resilience into the design of flood control alternatives. Journal of Hydrology, 576, 478-493.

Sugiyono, 2009, Metode Penelitian Kuantitatif, Kualitatif dan R\&D, Bandung : Alfabeta.

Sugiyono. (2012). Metode Penelitian Kuantitatif, Kualitatif, dan R\&D. Bandung: Alfabeta.

Wibowo, Y. A., Ronggowulan, L., Arif, D. A., Afrizal, R., Anwar, Y., \& Fathonah, A. (2019). Perencanaan Mitigasi Bencana Banjir NonStruktural Di Daerah Aliran Sungai Comal Hilir, Jawa Tengah. JPIG (Jurnal Pendidikan Dan Ilmu Geografi), 4(2), 87-100. https://doi.org/10.21067/jpig.v4i2.3632 